\title{
PENGARUH PEMAHAMAN PAJAK, KESADARAN WAJIB PAJAK DAN SANKSI PAJAK TERHADAP KEPATUHAN WAJIB PAJAK HOTEL DI SARANGAN MAGETAN
}

\author{
Niti Tri Rahayu ${ }^{1}$; Supri Wahyudi Utomo ${ }^{2}$; Liana Vivin Wihartanti ${ }^{3}$ \\ Pendidikan Akuntansi FKIP Universitas PGRI Madiun \\ Jln.Setia Budi 85 Madiun Jawa Timur \\ E-mail : lianavivin@unipma.ac.id \\ diterima: 4/11/2020; direvisi: 16/1/2021; diterbitkan: 26/9/2021
}

\begin{abstract}
This study aims to empirically examine the effect of understanding tax, awareness of taxpayers, and tax sanctions partially or simultaneously on hotel taxpayer compliance in Sarangan Magetan. This research uses a quantitative approach. The population is 125 taxpayers. The sample size of 56 taxpayers was determined by random sampling technique. The research instrument used a questionnaire. Data analysis techniques include the instrument test (validity and reliability test), the classic assumption test, multiple linear regression analysis, and hypothesis testing using t test and $F$ test. The results showed that: (1) positively influences tax understanding of hotel taxpayers compliance in Sarangan Magetan, (2) positively influences taxpayer awareness of hotel taxpayers compliance in Sarangan Magetan, (3) positively influences tax sanctions on hotel taxpayer compliance in Sarangan Magetan, (4) simultaneously influences the understanding of taxes, awareness of taxpayers, and tax sanctions on hotel taxpayer compliance in Sarangan Magetan.
\end{abstract}

Keywords: understanding, taxpayer awareness, sanctions, hotel tax

\section{PENDAHULUAN}

UU Nomor 16 Tahun 2009 Pasal 1 ayat (1) menyatakan pajak ialah kontribusi wajib setiap warga negara yang menjadi wajib pajak kepada negara terutang oleh orang pribadi atau badan bersifat memaksa berdasarkan UU, tidak mendapatkan imbalan langsung dan digunakan untuk keperluan negara serta kemakmuran rakyat.

Pajak daerah terdiri berbagai jenis, salah satunya adalah pajak hotel. Pajak hotel menurut (Anggoro et al., 2017) merupakan pajak atas fasilitas disediakan hotel. Pajak hotel merupakan komponen penerimaan pajak daerah. Keberadaan pajak hotel bagi pemerintah daerah menunjang Pendapatan Asli Daerah. Seperti terjadi di Pemerintah Kabupaten Magetan, keberadaan pajak hotel merupakan sumber pendapatan kabupaten.

Potensi wisata dimiliki Kabupaten Magetan telah mendatangkan wisatawan, baik lokal maupun luar
Kabupaten Magetan. Diimbangi menjamurnya usaha hotel, baik hotel berbintang, hotel melati, maupun villa, khususnya di objek wisata unggulan Kabupaten Magetan, yaitu Objek Wisata Telaga Sarangan. Mengingat pentingnya pajak hotel sebagai sumber PAD, Pemerintah Kabupaten Magetan melaksanakan berbagai upaya demi terwujudnya ketaatan wajib pajak membayar pajaknya. Kepatuhan wajib pajak menurut Nurmantu (Pohan, Chairil Anwar. 2016) merupakan keadaan wajib pajak memenuhi semua kewajiban dan melaksanakan hak perpajakannya.

Pemerintah Kabupaten Magetan melalui BPPKAD secara rutin menyelenggarakan sosialisasi perpajakan daerah meningkatkan ketaatan wajib pajak hotel membayar kewajiban pajakannya. Tujuan sosialisasi sebagai sarana meningkatkan pemahaman masyarakat tentang pajak daerah, termasuk di dalamnya pemahaman tentang pajak hotel. 
Jurnal Ilmiah Ekonomi dan Bísnis

Vol. 18. No.1,Maret 2021 : 57-64

EISSN : $2442-9813$

ISSN : $1829-9822$

Pemahaman pajak adalah pengetahuan aturan dan ketentuan perpajakan berlaku di Indonesia perlu dimiliki seluruh wajib pajak. Bahkan para wajib pajak hotel di Kabupaten Magetan memanfaatkan ketentuan perpajakan menguntungkan dirinya.

$$
\text { Kepatuhan wajib pajak }
$$

membayar pajak hotel di Kabupaten Magetan ditentukan seberapa besar kesadaran dimiliki wajib pajak untuk taat membayar pajak. Kesadaran dan kedisiplinan wajib pajak diperlukan untuk mematuhi kewajiban pajak, meliputi pengisian SPT, menghitung pajak, membayar pajak, dan melapor pajaknya.

Faktor lain mempengaruhi kepatuhan pajak membayar pajak hotel di Kabupaten Magetan adalah sanksi pajak. Temuan penelitian dilakukan (Arifin et al., 2017) bahwa sanksi pajak berpengaruh signifikan terhadap kepatuhan pajak. Sanksi dikenakan untuk setiap wajib pajak melanggar ketentuan peraturan UU pajak yaitu sanksi administrasi, sanksi pidana, atau keduanya.

Fenomena tentang pemahaman, wajib pajak belum memahami arti penting pajak hotel untuk menunjang pembangunan daerah. Wajib pajak awam mengisi SPT, menghitung pajak, menyetor pajak, melapor pajaknya. Hal ini dipengaruhi adanya latar belakang pendidikan relatif rendah $48,2 \%$ sebagai wajib pajak, dan bisnis hotel diperoleh dari meneruskan bisnis keluarga/warisan keluarga. Wajib pajak kurang up to date jika ada perubahan terkait peraturan pajak hotel disampaikan oleh petugas secara tertulis dan melalui telepon. Wajib pajak yang belum paham atas kesadaran membayar pajak, aturan membayar pajak, dan sanksi yang didapat jika terlambat membayar pajak akan mendorong wajib pajak untuk tidak patuh.
Penelitian ini bertujuan menguji secara empiris pengaruh pemahaman pajak, kesadaran wajib pajak, dan sanksi pajak terhadap kepatuhan wajib pajak hotel di Sarangan Magetan.

\section{TINJAUAN PUSTAKA}

Pemahaman

merupakan pengalaman mental, disampaikan Sierpinska dalam (Susanto, Herry Agus. 2019) bahwa pemahaman merupakan pengalaman mental menghubungkan antara objek satu dengan objek lainnya. Berkaitan perpajakan, pemahaman pajak (tax understanding) menurut Hardiningsih \& Yulianawati (2011) dalam (Ruky et al., 2018) adalah wajib pajak mengetahui tentang peraturan pajak dan melaksanakan kegiatan pajak seperti, membayar pajak, melaporkan SPT, serta mengetahui tarif pajak sesuai UU dan manfaat pajak.

Menurut (Mardiasmo. 2016), pajak merupakan iuran rakyat ke kas negara berdasarkan UU dipaksakan, tidak mendapat imbalan langsung dan digunakan membayar kepentingan umum negara. Contohnya pembangunan jalan, biaya pendidikan, dan kesehatan dikelola oleh pemerintah. Pajak hotel menurut (Anggoro, Damas Dwi. 2017) adalah pajak atas fasilitas disediakan oleh hotel. Pajak Hotel merupakan komponen penerimaan pajak kabupaten/kota termasuk pajak daerah.

Pengukuran pemahaman pajak penelitian ini indikator-indikator mengacu penelitian dilaksanakan (Ruky et al., 2018), meliputi: a) Wajib pajak memahami fungsi dan manfaat pajak hotel, b) Wajib pajak memahami cara membayar pajak hotel, c) Wajib pajak memahami peraturan pajak hotel, d) Wajib pajak memahami jika ada perubahan peraturan perpajakan hotel.

Kesadaran wajib pajak diartikan perilaku, pandangan atau persepsi melibatkan keyakinan, pengetahuan dan penalaran berperan sesuai dorongan dan 
ketentuan pajak yang berlaku (Ritonga. 2011).

Indikator kesadaran wajib pajak menurut (Ariesta et al., 2017a) meliputi: a) Wajib pajak tahu bahwa pajak sumber penerimaan negara, b) Wajib pajak tahu bahwa membayar pajak untuk menunjang pembangunan negara, dan c) Wajib pajak sadar bahwa menunda membayar pajak merugikan Negara.

Penelitian (Masruroh et al., 2013) menyampaikan bahwa wajib pajak patuh membayar pajak apabila memahami sanksi pajak akan merugikan diri sendiri. Sanksi pajak memberikan efek jera kepada wajib pajak yang melanggar peraturan pajak sehingga tercipta ketaatan melaksanakan kewajiban pajaknya. Menurut (Prasetyo et al., 2016) berdasarkan UU Nomor 28 Tahun 2007 tentang Perpajakan, 3 jenis sanksi wajib pajak melanggar peraturan pajak yaitu, (1) Sanksi Administrasi, (2) Sanksi Bunga, dan (3) Sanksi Pidana.

Instrumen digunakan untuk mengukur variabel sanksi perpajakan sesuai dengan (Suandy. 2011), a) Pengetahuan tentang sanksi pajak, dan b) Sikap seseorang terhadap sanksi pajak.

Menurut (Rahman, 2010) menyatakan bahwa kepatuhan pajak yaitu keadaan wajib pajak memenuhi kewajiban pajak dan melaksanakan hak pajaknya. Kepatuhan wajib pajak adalah ketaatan wajib pajak memenuhi kewajiban pajaknya sesuai peraturan pajak yang berlaku. Indikator kepatuhan wajib pajak menurut (Rahayu, 2013), a) kepatuhan mendaftarkan diri, b) kepatuhan menghitung dan membayar pajak terutang, c) kepatuhan membayar tunggakan pajak, d) kepatuhan menyetorkan kembali SPT.

\section{METODE PENELITIAN}

Penelitian dilaksanakan di kawasan objek wisata Telaga Sarangan Kabupaten Magetan, dan di BPPKAD
Kabupaten Magetan beralamat di Jalan Basuki Rahmat Timur, No. 1 Magetan. Berdasarkan data diperoleh jumlah populasi adalah 125 wajib pajak hotel. Menentukan jumlah sampel menggunakan Rumus Slovin, dalam (Siregar, 2014):

$$
n=\frac{N}{1+N(e)^{2}}
$$

\section{Definisi:}

$$
\begin{array}{ll}
n & : \text { sampel } \\
N & \text { : populasi } \\
e & \text { : margin of error }
\end{array}
$$

Berdasarkan rumus di atas:

$$
\begin{aligned}
n & =\frac{125}{1+125(0,1)^{2}} \\
& =\frac{125}{2,25}=55,56
\end{aligned}
$$

Sampel diperoleh 55,56 dibulatkan menjadi 56. Jumlah sampel adalah 56 wajib pajak hotel di Sarangan Magetan. Pengambilan sampel menggunakan teknik random sampling dengan cara diundi. Penentuan sampel sederhana, didukung pendapat (Sugiyono, 2017) menyatakan teknik random sampling sederhana karena pengambilan sampel dari populasi dilaksanakan secara acak tanpa menghiraukan strata di populasi.

Variabel penelitian tentang pengaruh pemhaman pajak, kesadaran wajib pajak, dan sanksi pajak terhadap kepatuhan wajib pajak hotel di Sarangan Magetan ini menggunakan 2 variabel yaitu variabel bebas dan variabel terikat. Definisi operasional penelitian ini yaitu berkaitan pemahaman pajak (tax understanding), (Susanto, Ahmad. 2016) menguraikan bahwa pemahaman diartikan dengan proses, cara, perbuatan memahami atau memahamkan. Dalam perpajakan, pemahaman pajak diartikan sebagai kemampuan wajib pajak untuk menangkap makna dan arti peraturan perpajakan. Kesadaran wajib pajak (tax awareness) merupakan perilaku wajib pajak berupa pandangan atau persepsi yang melibatkan keyakinan, pengetahuan dan penalaran serta kecenderungan untuk bertindak sesuai dengan stimulus yang 
Jurnal Ilmiah Ekonomi dan Bísnis

Vol. 18. No.1,Maret 2021 : 57-64

EISSN : $2442-9813$

ISSN : $1829-9822$

diberikan oleh sistem dan ketentuan perpajakan yang berlaku (Ritonga, 2011).

Sanksi pajak merupakan jaminan bahwa ketentuan peraturan perundangundangan perpajakan (norma perpajakan) akan dituruti/ditaati/ dipatuhi atau bisa dengan kata lain sanksi perpajakan merupakan alat pencegah (preventif) agar wajib pajak tidak melanggar norma perpajakan (Mardiasmo, 2016). Kepatuhan wajib pajak merupakan suatu keadaan wajib pajak memenuhi semua kewajiban perpajakan dan melaksanakan hak perpajakannya (Pohan et al. 2016) .

Teknik pengumpulan data, a) dokumen-dokumen tentang jumlah hotel dan sumbangan pajak hotel terhadap PAD Kabupaten Magetan, jumlah wajib pajak hotel di Sarangan Magetan, serta teori-teori tentang pemahaman pajak, kesadaran wajib pajak, sanksi pajak, dan kepatuhan wajib pajak dan jurnal terdahulu, b) kuesioner mengumpulkan data tentang persepsi responden. Teknik analisis data yang digunakan yaitu uji instrumen (uji validitas dan uji reliabilitas), uji asumsi klasik (uji normalitas, uji multikolinearitas, dan uji heteroskedastisitas), analisis regresi linier berganda, uji hipotesis menggunakan uji $\mathrm{t}$ dan uji $\mathrm{F}$, dan koefisien determinasi.

\section{HASIL DAN PEMBAHASAN}

Tabel 1. Hasil Statistik Deskriptif

\begin{tabular}{lcccc}
\hline \multicolumn{1}{c}{ Variabel } & Min. & Max. & Mean & $\begin{array}{c}\text { Std. } \\
\text { Dev }\end{array}$ \\
\hline $\begin{array}{l}\text { Pemahaman } \\
\text { Pajak }\end{array}$ & 26 & 37 & 31,89 & 3,200 \\
Kesadaran WP & 22 & 39 & 31,16 & 3,520 \\
Sanksi Pajak & 12 & 20 & 15,57 & 1,757 \\
Kepatuhan WP & 27 & 38 & 31,98 & 2,590 \\
\hline
\end{tabular}

Sumber: olah data peneliti tahun 2020

Berdasarkan tabel 1. menunjukkan nilai minimum, maksimum, mean dan standar deviasi masing-masing variabel. Standar deviasi sangat kecil dibandingkan mean, maka mean merupakan gambaran yang baik, yang digunakan representasi seluruh variabel.

Pengujian validitas dilakukan kepada 56 responden. Keputusan diambil berdasar nilai $\mathrm{r}_{\text {hitung }}$ dari seluruh item memiliki nilai $r_{\text {hitung }}$ lebih besar dari nilai $r_{\text {tabel }}(0,2632)$, maka semua item digunakan adalah valid. Berdasarkan uji validitas untuk masingmasing variabel memiliki status valid, karena nilai $r_{\text {hitung }}>r_{\text {tabel }}$ sebesar 0,2632.

Pengujian reliabiitas menunjukkan hasil koefisien reliabilitas instrument variabel $X_{1} 0,726$, instrument variabel $X_{2}$ 0,731, instrumen variabel $X_{3} \quad 0,719$, instrumen variabel $\mathrm{Y}$ 0,732 dengan nilai Cronbach Alpha di atas 0,70, yang memiliki makna bahwa keempat instrumen dinyatakan reliable atau memenuhi persyaratan.

Hasil uji normalitas menggunakan uji One Sample Kolmogorov-Smirnov, diketahui nilai Asymp.Sig (2-tailed) 0,092 berada di atas $\alpha=0,05$. Hal tersebut menunjukkan data berdistribusi secara normal. Hasil uji multikolinearitas bahwa nilai tolerance variabel $\mathrm{X}_{1} 0,710$, variabel $\mathrm{X}_{2}$ 0,696, dan variabel $\mathrm{X}_{3}$ 0,626. Nilai tolerance ketiga variabel bebas $>0,1$. Maka di antara variabel bebas tidak terjadi multikolinieritas. Nilai Variance Influence Factor (VIF) ketiga variabel bebas lebih kecil dari 10. Variabel $\mathrm{X}_{1} 1,409$, variabel $X_{2} 1,436$, dan variabel $X_{3} 1,597$, maka tidak terdapat korelasi di antara salah satu variabel bebas dengan variabel bebas lainnya. Persoalan multikolinearitas di antara variabel bebas dapat ditolerir. Dengan demikian, dapat dilaksanakan uji regresi dengan hasil signifikan. Hasil uji heteroskedastisitas nilai signifikansi Variabel $\mathrm{X}_{1} 0,483>0,05$, variabel $\mathrm{X}_{2} 0,458$ $>0,05$ dan variabel $X_{3} 0,884>0,05$. Maka membuktikan data tidak terjadi heteroskedastisitas atau telah memenuhi kriteria uji heteroskedastisitas.

Dari hasil uji regresi linier berganda diformulasikan persamaan regresi linier berganda: 
$\mathrm{Y}=0,911+0,231 \mathrm{X}_{1}+0,407 \mathrm{X}_{2}+$ $0,185 \mathrm{X}_{3}$

Nilai konstanta bernilai 0,911 ; menunjukkan variabel $\mathrm{Y}$ bernilai 0,911 apabila variabel $X_{1}, X_{2}$, dan $X_{3}$ sama dengan nol atau konstan. Variabel $\mathrm{X}_{1}$ 0,231 , variabel $X_{2} 0,407$, variabel variabel $\mathrm{X}_{3}$ 0,185, maka menunjukkan pengaruh positif terhadap variabel Y. Jika ketiga variabel bebas meningkat satu satuan, maka kepatuhan wajib pajak hotel di Sarangan Magetan juga meningkat.

Berdasarkan hasil analisis koefisien determinasi diketahui Adjusted $R$ Square adalah 0,631 atau $63,1 \%$ berarti $63,1 \%$ kepatuhan wajib pajak hotel di Sarangan Magetan dijelaskan oleh ketiga variabel bebas dan sisanya, yaitu 36,9\% dijelaskan faktor lain.

Tabel 2. Hasil Uji t

\section{Coefficients $^{\mathrm{a}}$}

\begin{tabular}{|c|c|c|c|c|c|}
\hline Model & $U n$ & $\mathrm{Coe}$ & $\begin{array}{l}\text { Std. } \\
\text { Coe }\end{array}$ & & \\
\hline $\begin{array}{l}1 \\
\text { (constant) }\end{array}$ & $\begin{array}{c}\text { B } \\
0,911\end{array}$ & $\begin{array}{l}\text { Std. E } \\
0,339\end{array}$ & Beta & $\begin{array}{c}\mathrm{T} \\
2,683\end{array}$ & $\begin{array}{l}\text { Sig. } \\
0,010\end{array}$ \\
\hline $\begin{array}{l}\text { Pemahama } \\
\text { n pajak }\end{array}$ & $\begin{array}{c}0,23 \\
1\end{array}$ & $\begin{array}{c}0,08 \\
4\end{array}$ & $\begin{array}{c}0,26 \\
7\end{array}$ & $\begin{array}{c}2,74 \\
7\end{array}$ & $\begin{array}{c}0,00 \\
8\end{array}$ \\
\hline $\begin{array}{l}\text { Kesadaran } \\
\text { WP }\end{array}$ & $\begin{array}{c}0,40 \\
7\end{array}$ & $\begin{array}{c}0,07 \\
9\end{array}$ & $\begin{array}{c}0,50 \\
5\end{array}$ & $\begin{array}{c}5,14 \\
2\end{array}$ & $\begin{array}{c}0,00 \\
0\end{array}$ \\
\hline $\begin{array}{l}\text { Sanksi } \\
\text { pajak }\end{array}$ & $\begin{array}{c}0,18 \\
5\end{array}$ & $\begin{array}{c}0,09 \\
1\end{array}$ & $\begin{array}{c}0,21 \\
0\end{array}$ & $\begin{array}{c}2,02 \\
5\end{array}$ & $\begin{array}{c}0,04 \\
8\end{array}$ \\
\hline
\end{tabular}

Sumber: Olah data peneliti tahun 2020

Hasil pengujian diperoleh nilai $t_{\text {hitung variabel } X_{1} 2,747>t_{\text {tabel }}(2,00665)}$ dan Sig. $(0,008)<\alpha(0,05)$, variabel $\mathrm{X}_{2}$ $5,142>t_{\text {tabel }}(2,00665)$ dan Sig. $(0,000)<$ $\alpha(0,05)$, dan nilai $t_{\text {hitung }}$ variabel $X_{3} 2,025$ $>t_{\text {tabel }}(2,00665)$ dan Sig. $(0,048)<\alpha$ $(0,05)$, maka $\mathrm{H}_{\mathrm{o}}$ ditolak dan $\mathrm{H}_{\mathrm{a}}$ diterima. Dengan demikian hipotesis penelitian menyatakan "Ada pengaruh dari ketiga variabel bebas terhadap kepatuhan wajib pajak hotel di Sarangan Magetan”.

Tabel 3. Hasil Uji F

\begin{tabular}{llllll} 
Model & $\begin{array}{c}\text { Sum of } \\
\text { Squares }\end{array}$ & Df & $\begin{array}{c}\text { Mean } \\
\text { Square }\end{array}$ & $\boldsymbol{F}$ & Sig. \\
\hline Reg. & 4,206 & 3 & 1,402 & 32,304 & $.000^{\mathrm{b}}$ \\
Res. & 2,257 & 52 & 0,043 & & \\
Total & 6,462 & 55 & & & \\
\hline
\end{tabular}

Sumber: olah data peneliti tahun 2020

Hasil perhitungan menunjukkan nilai $F_{\text {hitung }}$ sebesar 32,304. Jumlah sampel adalah 56 orang responden. Banyak variabel bebas dan terikat $=4$, sehingga nilai $d f_{1}=\mathrm{k}-1=4-1=3$ dan $d f_{2}=56-4=$ 52. Tabel $\mathrm{F}_{0,05}, d f(3)(52)$ nilai $\mathrm{F}_{\text {tabel }}=2,78$. $F_{\text {hitung }}(32,304)$ lebih besar dari $F_{\text {tabel }}(2,78)$ dan nilai $p$-value $=0,000$ lebih kecil dari level of significant $(\alpha=0,05)$, maka $\mathrm{H}_{\mathrm{o}}$ ditolak dan $\mathrm{H}_{\mathrm{a}}$ diterima. Hal ini terdapat pengaruh simultan ketiga variabel bebas terhadap kepatuhan wajib pajak. Dengan demikian hipotesis penelitian $\left(\mathrm{H}_{4}\right)$ menyatakan "Ada pengaruh pemahaman pajak, kesadaran wajib pajak, dan sanksi pajak terhadap kepatuhan wajib pajak hotel di Sarangan Magetan".

Hasil penelitian ini mendukung temuan observasi dilaksanakan (Ruky et al., 2018) bahwa pemahaman peraturan pajak berpengaruh terhadap kepatuhan wajib pajak pada Kantor Bersama Samsat Kota Jambi. Pada observasi dilaksanakan (Widyaningsih et al., 2019) juga terbukti bahwa terdapat pengaruh yang positif pemahaman peraturan pajak terhadap kepatuhan membayar pajak hotel dan restoran di Kabupaten Badung. Memahami peraturan pajak yang berlaku merupakan hal penting bagi wajib pajak. Fenomena yang terjadi wajib pajak masih belum memahami peraturan perpajakan. Masih adanya wajib pajak menunggu ditagih, kemudian membayar pajak. Kejadian berdampak menurunnya jumlah penerimaan pajak dan tingkat kepatuhan wajib pajak.

Menurut jawaban wajib pajak hotel dari pernyataan-pernyataan bahwa mereka telah mengerti fungsi dan manfaat pajak hotel. Wajib pajak hotel paham bahwa membayar pajak sangat penting karena untuk membiayai pembangunan di Kabupaten Magetan. Wajib pajak mengetahui cara pembayaran pajak hotel, yaitu tidak mengalami kesulitan dalam menghitung jumlah pajak hotel yang harus dibayar serta telah membayar pajak melalui petugas yang datang atau membayar 
Jurnal Ilmiah Ekonomi dan Bisnis

Vol. 18. No.1,Maret 2021 : 57-64

EISSN : $2442-9813$

ISSN : $1829-9822$

langsung di loket BPPKAD dengan tepat waktu. Selain itu, menurut wajib pajak hotel di Sarangan, pihak BPPKAD Kabupaten Magetan sering menyampaikan informasi tentang perubahan peraturan pajak hotel, sehingga wajib pajak hotel selalu up to date terhadap peraturan tentang pajak hotel.

Di dukung temuan penelitian dilakukan (Ruky et al., 2018) bahwa kesadaran wajib pajak berpengaruh terhadap kepatuhan wajib pajak pada Kantor Bersama Samsat Kota Jambi. Kesadaran merupakan hal penting dimiliki wajib pajak, kesadaran melaksanakan kewajiban pajak untuk pembiayaan nasional. Terbukti kesadaran wajib pajak berpengaruh secara positif terhadap kepatuhan wajib pajak hotel Di Sarangan Magetan. Menurut wajib pajak hotel di Sarangan sebagai responden penelitian, dirinya sadar pendapatan daerah bersumber dari pajak daerah sangat penting bagi pelaksanaan pembangunan dan peduli terhadap fungsi dan manfaat pajak hotel yang saya bayar bagi pemerintah Kabupaten Magetan. Responden menyadari membayar pajak kewajiban sebagai warga negara berpartisipasi untuk pembangunan. Wajib pajak menyadari bahwa menunda membayar pajak hotel merugikan pemerintah daerah. Menurut responden, membayar pajak harus tepat waktu demi mendukung kelancaran pembangunan, khususnya yang ada di Kabupaten Magetan. Wajib pajak mengetahui jumlah iuran harus dibayar, sehingga saya membayar sesuai jumlah ditetapkan menurut ketentuan berlaku.

Didukung temuan (Arifin et al., 2017) yang berhasil membuktikan bahwa sanksi perpajakan berpengaruh signifikan terhadap kepatuhan wajib pajak. Sanksi adalah suatu tindakan berupa hukuman kepada wajib pajak orang atau badan melanggar peraturan. Sanksi pajak merupakan jaminan peraturan pajak ditaati atau dipatuhi. Menurut jawaban kuesioner disampaikan wajib pajak hotel di Sarangan Magetan, diketahui pendapat wajib pajak hotel terhadap sanksi pajak kriteria baik. Diindikasikan pengetahuan wajib pajak tentang sanksi perpajakan. Menurut responden, dirinya tahu setiap tindakan menghindari pajak harus dikenakan denda. Responden yakin pengenaan sanksi perpajakan benar-benar dilaksanakan secara adil terhadap semua subjek pajak.

Didukung temuan penelitian dilakukan (As'ari et al., 2018) bahwa pemahaman peraturan perpajakan, kesadaran wajib pajak dan sanksi pajak berpengaruh terhadap kepatuhan wajib pajak orang pribadi. Kepatuhan perpajakan menurut Nurmantu (Pohan, Chairil Anwar. 2016) merupakan "Keadaan wajib pajak memenuhi kewajiban pajak dan melaksanakan hak pajaknya." Kepatuhan wajib pajak daerah merupakan permasalahan penting bagi pemerintah daerah di Indonesia. Meningkatkan kepatuhan wajib pajak, Pemerintah Kabupaten Magetan melaksanakan dalam meningkatkan pemahaman pajak, kesadaran wajib pajak, serta menerapkan denda pajak demi tercapainya peningkatan kesadaran wajib pajak hotel. Wajib pajak hotel di Sarangan Magetan, diketahui kepatuhan wajib pajak hotel kriteria tinggi. Diindikasikan dari taat mendaftarkan diri, taat menghitung dan membayar pajak, taat membayar tunggakan pajak, dan taat menyetorkan kembali SPT. Wajib pajak hotel mendaftarkan NPWPD sesuai syarat subyektif dan obyektif. Responden menyampaikan SPT tepat waktu sesuai peraturan berlaku, menghitung pajak terutang secara benar serta menyetorkan tepat waktu sesuai peraturan berlaku. Wajib pajak hotel mengisi SPT sesuai ketentuan UU dan segera melaporkan SPT tanpa menunggu batas waktu yang telah ditentukan dan ketika mendapat peringatan dari petugas. Kepatuhan wajib pajak hotel di Sarangan Magetan dapat dianalisis melalui faktor-faktor pemahaman pajak, kesadaran wajib pajak, dan sanksi pajak. 
Pemahaman pajak, kesadaran wajib pajak dan sanksi pajak secara parsial maupun secara simultan berpengaruh terhadap kepatuhan wajib pajak hotel di Sarangan Magetan.

\section{KESIMPULAN DAN SARAN}

Pemahaman pajak, kesadaran wajib pajak, dan sanksi pajak berpengaruh positif terhadap kepatuhan wajib pajak hotel di Sarangan Magetan. Dengan adanya sosialisasi tentang pemahaman pajak untuk mendukung kepatuhan wajib pajak. Wajib pajak sadar pajak hotel menunjang pembangunan daerah, dan wajib pajak sadar bahwa menunda membayar pajak merugikan pemerintah. Didukung sosialisasi sanksi pajak demi terciptanya kepatuhan membayar pajak. Wajib pajak mengetahui adanya sanksi perpajakan, dan sikap wajib pajak terhadap sanksi perpajakan. Didukung wajib pajak patuh untuk mendaftarkan diri sebagai wajib pajak, patuh dalam menghitung dan membayar pajak, dan patuh untuk menyetor kembali surat pemberitahuan.

Berdasarkan

simpulan

disampaikan saran (a) Instansi pajak dapat meningkatkan kualitas pelayanan pajak, mendorong wajib pajak patuh melaksanakan kewajiban pajak. (b) BPPKAD bekerjasama dengan paguyuban yang ada melaksanakan sosialisasi terkait variabel secara langsung atau melalui media pendukung seperti adanya grup WA. (c) Wajib pajak meningkatkan kepatuhan memenuhi kewajiban pajaknya, meningkatkan pengetahuan dan pemahaman terhadap peraturan pajak, sehingga wajib pajak jujur melaporkan pajaknya. Wajib pajak aktif tanya jawab di paguyuban untuk menekankan pemahaman dan kesadaran akan pentingnya pajak hotel, mengetahui sanksi pajak, dan peraturan-peraturan pajak yang ada. (d) Penelitian selanjutnya meneliti lebih dalam tidak terbatas ketiga variabel dalam kaitannya kepatuhan wajib pajak hotel, perlu penambahan variabel lain seperti menambahkan tax amnesty, inspeksi pajak, dan sosialisasi perpajakan serta diharapkan menggunakan cakupan obyek penelitian lebih luas.

\section{DAFTAR PUSTAKA}

Anggoro, D. D. (2017). Pajak Daerah dan Retribusi Daerah. Universitas Brawijaya Press.

Ariesta, R. P. (2017). Pengaruh Kesadaran Wajib Pajak, Sanksi Perpajakan, Sistem Administrasi Perpajakan Modern , Pengetahuan Korupsi , dan Tax Amnesty Terhadap Kepatuhan Wajib Pajak di KKP Pratama Semarang Candisari (Dotoral dissertation Univeristas Negeri Semarang.

Arifin, S. B., \& Nasution, A. A. (2017). Pengaruh Kualitas Pelayanan dan Sanksi Perpajakan Terhadap kepatuhan Wajib Pajak Badan di KPP Pratama Medan belawan. Jurnal Akuntansi Dan Bisnis:

Arifin, S. B., \& Nasution, A. A. (2017). Pengaruh Kualitas Pelayanan dan Sanksi Perpajakan Terhadap Kepatuhan Wajib Pajak Badan di KPP Pratama Medan Belawan. Jurnal Akuntansi dan Bisnis: Jurnal Program Studi Akuntansi, 3(2).

Arikunto, S. (2013). Prosedur Penelitian Suatu Pendekatan Praktik. Edisi Revisi. Cetakan Kedelapan. Jakarta: Penerbit Rineka Cipta.

Sanjaya, H. Ghozali, I.(2016). Aplikasi Analisis Multivariete dengan Program IBM SPSS 23 (VIII). Semarang: Badan Penerbit Universitas Diponegoro.

Mardiasmo. (2016). Perpajakan. Edisi 
Jurnal Ilmiah Ekonomi dan Bísnis

Vol. 18. No.1,Maret 2021 : 57-64

EISSN : $2442-9813$

ISSN : $1829-9822$

Revisi. Yogyakarta: Penerbit Andi.

Masruroh, S., \& Zulaikha, Z. (2013). Pengaruh Kemanfaaatan Npwp, Pemahaman Wajib Pajak, Kualitas Pelayanan, Sanksi Perpajakan Terhadap Kepatuhan Wajib Pajak (Studi Empiris pada WP OP di Kabupaten Tegal). Diponegoro Journal Of Accounting, 435449.

Nurkhin, A., Novanty, I., Muhsin, M., \& Sumiadji, S. (2018). The influence of tax understanding, tax awareness and tax amnesty toward taxpayer compliance. Jurnal Keuangan dan Perbankan, 22(2), 240-255

Pohan, C. A. D. (2016). Pedoman Lengkap Pajak Pertambahan Nilai. Teori Konsep, dan Aplikasi PPN. PT. Gava medi. Yogyakarta.

Prasetyo, A. (2017). Konsep dan analisis rasio pajak. Elex Media Komputindo.

Rahayu, S. K. (2013). Perpajakan Indonesia Konsep \& Aspek Formal.. Graha Ilmu. Yogyakarta

Rahman, A. (2010). Panduan Pelaksanaan Administrasi Perpajakan Untuk Karyawan, Pelaku Bisnis dan Perusahaan. Bandung: Nuansa.

Wibowo, A., Rispantyo, R., \& Widajanti, E. (2020). Pengaruh Pengetahuan Perpajakan, Kesadaran Wajib Pajak, Kualitas Pelayanan Pajak Dan Sanksi Pajak Terhadap Kepatuhan Wajib Pajak Daerah Lain Kabupaten Ponorogo.
Jurnal Manajemen Sumber Daya Manusia, 14.

Putra, W. E., \& Mansur, F. (2018). Pengaruh Pemahaman Peraturan Perpajakan, Kesadaran Wajib Pajak, Akuntabilitas Pelayanan Publik Dan Kewajiban Moral Terhadap Kepatuhan Wajib Pajak (Studi Empiris pada Kantor Bersama SAMSAT Kota Jambi). Jurnal Riset Akuntansi dan Keuangan, 6(3), 405-418.

Siregar, S. (2014). Metode Penelitian Kuantitatif Dilengkapi dengan Perbandingan Perhitungan Manual dan SPP Versi 17. Jakarta: Kencana Persada Media Group.

Suandy, E. (2011). Perencanaan Pajak, Edisi 5. Jakarta: Salemba Empat.

Sugiyono, P. D. (2017). Metode Penelitian Pendidikan: Pendekatan Kuantitatif, Kualitatif, R\&D (Cetakan Ke). Bandung: CV Alfabeta.

Ahmad Susanto, M. P. (2016). Teori belajar dan pembelajaran di sekolah dasar. Kencana.

Susanto, H. A. (2015). Pemahaman Pemecahan Masalah Berdasar Gaya Kognitif. Deepublish.

Widyaningsih, N. K. A. (2019). Pengaruh Pemahaman Peraturan Pajak, Penerapan Kebijakan Pajak dan Kemudahan Administrasi Pajak Terhadap Kepatuhan Wajib Pajak Hotel dan Restoran Di Kabupaten Badung. JSAM (Jurnal Sains, Akuntansi dan Manajemen), 1 (2), 78-106 